Kharchenko A. V., Yelinska A. M. DNA typing of the gastric mucosa of patients with chronic duodenal ulcer. Journal of Education, Health and Sport. 2021;11(11):221-230. eISSN 2391-8306. DOI http://dx.doi.org/10.12775/JEHS.2021.11.11.022 https://apcz.umk.pl/JEHS/article/view/JEHS.2021.11.11.022

https://zenodo.org/record/5767872

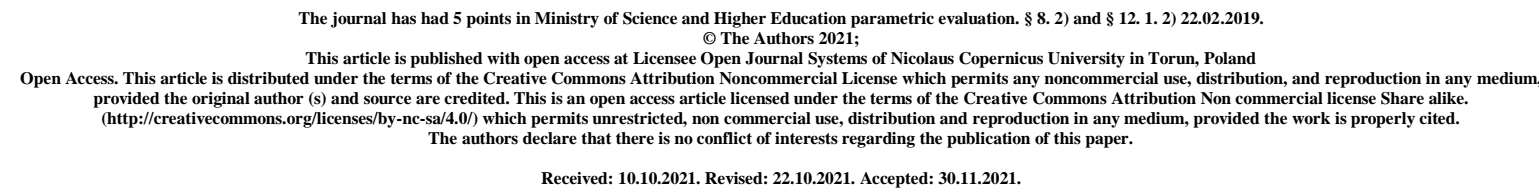

UDC 616.33-002

\title{
DNA TYPING OF THE GASTRIC MUCOSA OF PATIENTS WITH CHRONIC DUODENAL ULCER
}

\author{
A. V. Kharchenko, A. M. Yelinska \\ Petro Mohyla Black Sea National University, Mykolayiv, Ukraine \\ kharchenko7591@gmail.com
}

Connection of work with scientific programs, plans, topics. The work is a fragment of the research project "Determination of pathomorphological differential diagnostic markers of precancerous processes and tumors of the epithelial tissue of the stomach", № state registration 0120U002028.

\section{Abstract}

The work involved a molecular biological technique (ISSR-PCR) using ISSR-primer S-2, with structure (AGC) 6G. Changes in the gastric mucosa in chronic duodenal ulcer disease against the background of severe chronic atrophic gastritis have been analyzed. Noteworthy is the fact that there is a strong correlation between the degree of dysplasia of the epithelium of the gastric mucosa and the mitotic index, the Pearson's correlation coefficient $\mathrm{r}_{\mathrm{xy}}$ was 0.853 , respectively. A strong and very strong correlation relationship between the indicators of the degree of dysplasia of the epithelium of the gastric mucosa by phenotypic characteristics and indicators of DNA typing of samples of the gastric mucosa, the Pearson's correlation coefficient rxy was 0.863 , respectively.

DNA profiles of the gastric mucosa of patients with duodenal ulcer according to the results of typing by the ISSR-PCR method ranging from 520 to $620 \mathrm{bp}$. had the character of 
microsatellite expansions and differed from the profile of the norm, which is evidence of precancerous changes.

Key words: genotyping; DNA profiles; microsatellite expansions.

\title{
ДНК-ТИПУВАННЯ СЛИЗОВОЇ ОБОЛОНКИ ШЛУНКА ХВОРИХ НА ХРОНІЧНУ ВИРАЗКУ ДВАНАДЦЯТИПАЛОЇ КИШКИ
}

\author{
О. В. Харченко, А. М. Слінська \\ Чорноморський національний університет імені Петра Могили, \\ м. Миколаїв, Україна
}

В роботі задіяна молекулярно-біологічна методика (ISSR-PCR) з використанням ISSR -праймеру S-2, із структурою (AGC)6G.

Проаналізовані зміни слизової оболонки шлунка при хронічній виразковій хворобі дванадцятипалої кишки на фоні вираженого хронічного атрофічного гастриту. Звертає на себе увагу той факт, що існує сильний за тіснотою зв'язок між ступенем дисплазії епітелію слизової оболонки шлунка та мітотичним індексом коефіцієнт кореляції Пірсона $\mathrm{r}_{\mathrm{xy}}$ склав відповідно 0,853. Сильний і дуже сильний за тіснотою кореляційний зв'язок між показниками ступеня дисплазії епітелію слизової оболонки шлунка за фенотипічними ознаками і показниками ДНК-типування зразків слизової

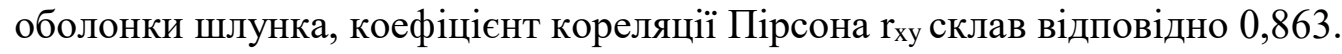

ДНК-профілі слизової оболонки шлунка хворих на виразку дванадцятипалої кишки за результатами проведення типування методом ISSR-PCR розміром від 520 до 620 п.н. мали характер мікросателітних експансій, та були відмінні від профілю норми, що є свідченням передракових змін.

Ключові слова: генотипування; ДНК - профілі; мікросателітні експансії. 


\title{
ДНК-ТИПИРОВАНИЕ СЛИЗИСТОЙ ОБОЛОЧКИ ЖЕЛУДКА БОЛЬНЫХ С ХРОНИЧЕСКОЙ ЯЗВОЙ ДВЕНАДЦАТИПЕРСТНОЙ КИШКИ
}

\author{
А. В. Харченко, А. Н. Елинская
}

\section{Черноморский национальній университет имени Петра Могилы, \\ г. Николаев, Украина}

В работе задействована молекулярно-биологическая методика (ISSR-PCR) c использованием ISSR-праймера S-2, со структурой (AGC)6G.

Проанализированы изменения слизистой желудка при хронической язвенной болезни двенадцатиперстной кишки на фоне выраженного хронического атрофического гастрита. Обращает на себя внимание тот факт, что существует сильная по тесноте связь между степенью дисплазии эпителия слизистой желудка и митотическим индексом, коэффициент корреляции Пирсона $\mathrm{r}_{\mathrm{xy}}$ составил соответственно 0,853 . Сильная и очень сильная по тесноте корреляционная связь между показателями степени дисплазии эпителия слизистой желудка по фенотипическим признакам и показателям ДНК-типирования образцов слизистой оболочки желудка, коэффициент корреляции Пирсона гху составил соответственно $0,863$.

ДНК-профили слизистой желудка больных язвой двенадцатиперстной кишки по результатам проведения типирования методом ISSR-PCR размером от 520 до 620 п.н. имели характер микросателлитных экспансий и отличались от профиля нормы, что является свидетельством предраковых изменений.

Ключевые слова: генотипирование; ДНК - профили; микросателлитные экспансии.

Introduction. In 2003, an official proclamation was made to decipher the human genome. Due to the real possibility of analysis of genetic material in biomedical science, there is a rapid change in views on the etiology and pathogenesis, morphology and morphogenesis of gastric cancer [2]. There is an active introduction of new terms in biomedical science [4]. Views on the differential diagnosis of precancerous processes and gastric cancer are changing $[6,7,10]$. Among precancerous diseases of the stomach, the central place is given to chronic gastritis, on the background of which and in connection with which precancerous changes occur $[8,9,11]$. 
Not so long ago, only classical methods of cytology and histology were actively used to diagnose oncological neoplasms. However, in recent decades, classical approaches have been rapidly replaced by molecular genetic markers, which most adequately meet the set of requirements for markers: highly polymorphic nature, codominant type of inheritance, wide genome representation, available methods, high reproducibility, the ability to exchange data between laboratories [5].

The search for convenient and fast ways to visualize DNA polymorphism in recent years has led to the emergence of a wide range of technologies. Among the many techniques based on the use of PCR, a special place is occupied by markers that are fragments of DNA located between the loci of invert DNA repeats: ISSR (Inter simple sequence repeats). Most microsatellite mutations are associated with insertions or deletions of some repeats that occur during replication. Such a violation of the stability of microsatellites most often occurs due to the formation of loops on DNA during replication ("slippage") [3].

The level of frequency of transcriptional looping varies. The relationship between the number of such mutations and the size of microsatellite DNA is directly proportional [1], and for four nucleotide repeats - exponential. Intensive lengthening of microsatellite sequences due to replication errors is called microsatellite expansion [12].

The aim of the study was to identify the phenomenon of microsatellite expansions in precancerous processes of the gastric mucosa.

\section{Material and methods of research}

Examination of DNA of the gastric mucosa using ISSR-PCR method in patients with duodenal ulcer. Individual DNA typing (genotyping) of samples of gastric mucosa was performed by amplification of DNA in polymerase chain reaction (PCR) using ISSR - primer S2, which had the structure: (AGC) 6 G.

Amplification was performed in $25 \mu$ of the reaction mixture containing $1 \times$ reaction buffer with triphosphates, primer of the induced structure, Tag polymerase (Tapotili, Institute of Genetics, Russia), DNA was added in an amount of 10 - 20 ng per reaction. The annealing temperature of the primer was $57^{\circ} \mathrm{C}$, the synthesis of DNA fragments took place in 30 cycles of amplification on a thermocycler (amplifier) "Tertsyk" TP4-PCR 01 ("DNA - technology", Russia) in the mode: I - $95^{\circ}-2$ min., II $-94^{\circ}-30 \mathrm{~s}, 57^{\circ}-2 \mathrm{~min}, 72^{\circ}-2 \mathrm{~min}$, III $-72^{\circ}-10 \mathrm{~min}$.

Electrophoretic separation of amplification products was performed in $2 \%$ horizontal agarose gel (Vagofor, Latvia) in $1 \times$ TBE buffer, followed by staining for $10 \mathrm{~min}$ in $0.5 \mu \mathrm{g} /$ $\mathrm{ml}$ ethidium bromide solution and repeated washing in running water. 
Visualization of electrophoregrams was performed on a transilluminator in UV light with a wavelength of $365 \mathrm{~nm}$, followed by photography.

Amplicon sizing was performed using a 1000 bp molecular weight marker DNALedder, pUC 19 DNA / Msp I (Fermentas, Lithuania).

\section{Research results and their discussion}

Genotyping of the epithelium of the gastric mucosa of patients with chronic duodenal ulcer, revealed a variety of amplification profiles of DNA of the gastric mucosa.

Among the variety of samples it was possible to group DNA profiles according to the phenotypic signs of dysplasia (D-I - D-III) and to identify PCR types by maximum expression in each case (Fig. 1).

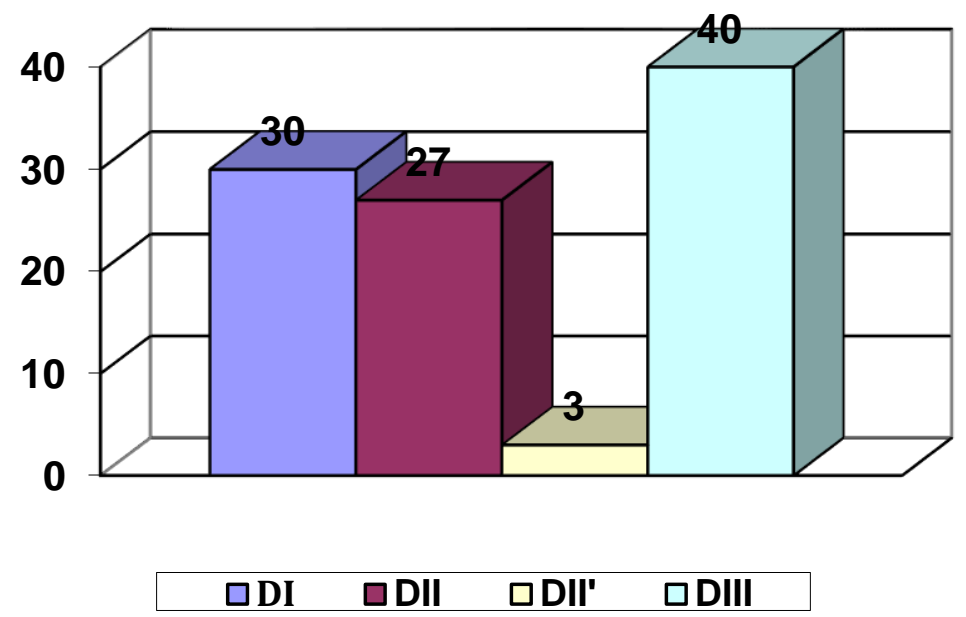

Fig. 1. Distribution of DNA profiles of the gastric mucosa in patients with chronic duodenal ulcer(CDU)

Profiles of the gastric mucosal marker normally contained fragments of 190, 180, 160, 140, 120, 110, 90, 70, $60 \mathrm{np}$ (nucleotide pairs) and were identical within their group, but significantly different from DNA profiles other study groups. DNA profiles of 220, 210, 200, 190, 180, 160, 140, 120, 110, 100, $90 \mathrm{np}$. corresponded to the phenotype D-I. But phenotypes D-II in $90 \%$ of cases had a variant of DNA profiles of 300, 260, 240, 220, 210, 190, 180, 160, 140, 120, $100 \mathrm{np}$ (the first option), the rest had a small DNA profiles (second option) 500, 480, 440, 400, 360, 300, 240, 200, 140, 110, $100 \mathrm{np}$ (Fig. 2), however, phenotypes D-III had DNA profiles of only one variant in size 520, 500, 480 460, 440, 420, 410, 380, 360,340,320 np (Fig. 3). 


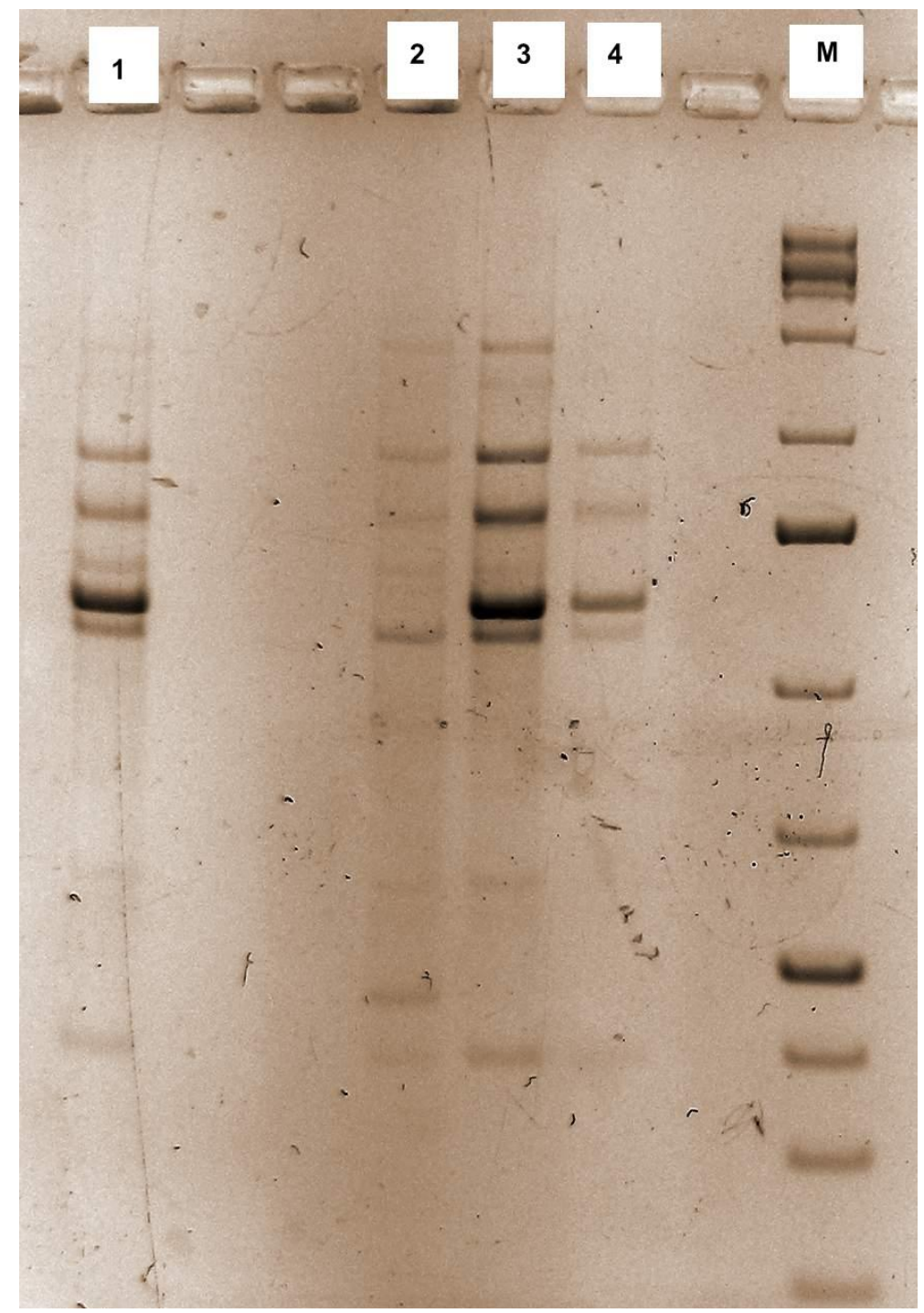

Fig. 2. Electrophoregrams of products of amplification of DNA samples of gastric mucosa DII: 1, 4 - amplification profiles D-II of the first option; 2,3 - amplification profiles D-II of the second option; $\mathrm{M}$ is a marker of the size of DNA fragments

DNA profiles of the gastric mucosa corresponding to the D-I phenotype had some similarity (63.6\% similarity) with the normal marker.

Phenotype D-II corresponded to two variants of DNA profiles with the presence of amplicons with a size within $500 \mathrm{np}$ and without them. The latter had significant similarity at the level of $36.4 \%$ with the DNA profiles of the gastric mucosa type D-III. This indicates that DNA profiles of D-II change and have transitional forms of PCR type D-III. 


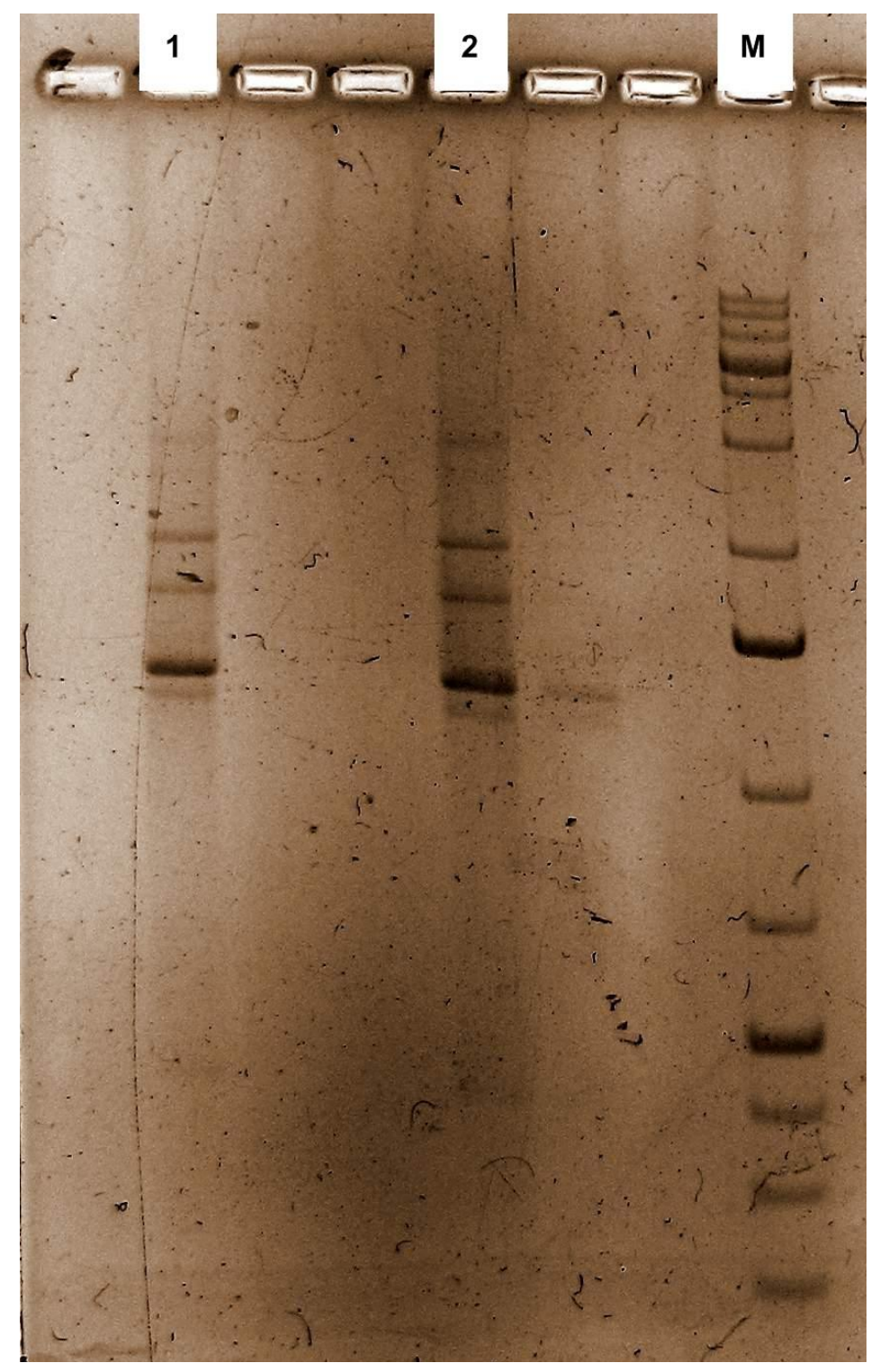

Fig. 3. Electrophoregrams of products of amplification of DNA samples of gastric mucosa: 1,2 - profiles D-III; $\mathrm{M}$ is a marker of the size of DNA fragments

DNA profiles of the gastric mucosa with D-III contained amplicons of $520 \mathrm{np}$ and were genetically different from other observation groups, but were similar within their group.

Between the degree of dysplasia of the epithelium of the gastric mucosa by phenotypic characteristics and DNA typing of gastric mucosa samples, the Pearson correlation coefficient $\mathrm{r}_{\mathrm{xy}}$ is 0.863 and 0.917 , respectively, which means a strong and very strong correlation between the indicators. The coefficient of determination $\mathrm{D}=\mathrm{r}_{\mathrm{xy}} \wedge 2$ was 0.744 and 0.842 , respectively. The critical value of the correlation coefficient with a probability of 0.95 was 0.2732 . The critical value of the correlation coefficient with a probability of 0.99 was 0.3511 . Comparison of the correlation coefficient $r_{x y}$ with the critical (tabular) value of $r_{c r}$ for a significance of 0.95 
corresponded to $r_{x y}>r_{c r .}$. Comparison of the correlation coefficient $r_{x y}$ with the critical (tabular) value of $r_{c r}$ for a significance of 0.99 corresponded to $r_{x y}>r_{c r}$. The covariance coefficient was 78.673 and 100.898, respectively, which allows us to conclude a statistically significant relationship between these indicators with a probability of 0.99 (Table 1).

Table 1

The results of correlation analysis of mucosal parameters

gastric mucosa in chronic duodenal ulcer

\begin{tabular}{|c|c|c|c|}
\hline & $\begin{array}{l}\text { The degree of } \\
\text { dysplasia - } \\
\text { DNA type min }\end{array}$ & $\begin{array}{l}\text { The degree of } \\
\text { dysplasia - } \\
\text { DNA type } \\
\text { max }\end{array}$ & $\begin{array}{l}\text { Degree of } \\
\text { dysplasia - } \\
\text { Mitotic index }\end{array}$ \\
\hline The Pearson correlation coefficient $r_{x y}$ & 0,863 & 0,917 & 0,853 \\
\hline Closeness of communication & strong & very strong & strong \\
\hline Coefficient of determination $\mathrm{D}=\mathrm{r}_{\mathrm{xy}} \wedge 2$ & 0,744 & 0,842 & 0,727 \\
\hline $\begin{array}{l}\text { The critical value of the correlation } \\
\text { coefficient with probability } 0,95\end{array}$ & 0,2732 & 0,2732 & 0,2732 \\
\hline $\begin{array}{l}\text { The critical value of the correlation } \\
\text { coefficient with probability } 0,99\end{array}$ & 0,3511 & 0,3511 & 0,3511 \\
\hline $\begin{array}{l}\text { Comparison of the correlation } \\
\text { coefficient } r_{x y} \text { with the critical (tabular) } \\
\text { value of } r_{c r} \text { for a significance } 0,95\end{array}$ & $r_{x y}>r_{c r}$ & $r_{x y}>r_{c r}$ & $r_{x y}>r_{c r}$ \\
\hline $\begin{array}{l}\text { Comparison of the correlation } \\
\text { coefficient } r_{x y} \text { with the critical (tabular) } \\
\text { value of } r_{c r} \text { for a significance of } 0,99\end{array}$ & $r_{x y}>r_{c r}$ & $r_{x y}>r_{c r}$ & $r_{x y}>r_{c r}$ \\
\hline Covariance coefficient & 78,673 & 100,898 & 2,824 \\
\hline Conclusion & $\begin{array}{c}\text { statistically } \\
\text { significant } \\
\text { dependence } \\
\text { with } \\
\text { probability } \\
0,99\end{array}$ & $\begin{array}{c}\text { statistically } \\
\text { significant } \\
\text { dependence } \\
\text { with } \\
\text { probability } \\
0,99\end{array}$ & $\begin{array}{c}\text { statistically } \\
\text { significant } \\
\text { dependence } \\
\text { with } \\
\text { probability } \\
0,99\end{array}$ \\
\hline
\end{tabular}

Between the degree of dysplasia of the epithelium of the gastric mucosa and the indicators of the mitotic regime: mitotic index, the Pearson correlation coefficient $r_{x y}$ was 0.853, respectively, indicating the presence of a strong connection. The coefficient of determination $\mathrm{D}=\mathrm{r}_{\mathrm{xy}} \wedge 2$ was 0.727 , respectively. The critical value of the correlation coefficient with a probability of 0.95 was 0.2732 . The critical value of the correlation coefficient with a probability of 0.99 was 0.3511 . Comparison of the correlation coefficient $r_{x y}$ with the critical (tabular) value of $r_{c r}$ for a significance of 0.95 corresponded to $r_{x y}>r_{c r}$. Comparison of the correlation coefficient $r_{x y}$ with the critical (tabular) value of $r_{c r}$ for a significance of 0.99 corresponded to $r_{x y}>r_{c r}$. The covariance coefficient was 2,824 , 
respectively. This makes it possible to conclude that there is a statistically significant dependence with a probability of 0.99 (Table 1.).

\section{Conclusions}

There is a strong relationship between the degree of gastric mucosal epithelial dysplasia and the mitotic index, the Pearson correlation coefficient $r_{x y}$ was 0.853 , respectively. Strong and very close in correlation between the indicators of the degree of dysplasia of the epithelium of the gastric mucosa on phenotypic characteristics and indicators of DNA typing of samples of gastric mucosa, Pearson's correlation coefficient $r_{x y}$ was 0.863 , respectively.

DNA profiles of the gastric mucosa of patients with duodenal ulcer according to the results of ISSR-PCR typing in each case are detected by the maximum expression of dysplasia.

If dysplasia from D-I to D-III was detected phenotypically in the mucosa, the genotyping result corresponded to the maximum D-III with DNA profiles having amplicons $520 \mathrm{np}$ in length. Amplification profiles D-II have two options, but the other option has some similarities to the profile D-III.

Revealed fairly stable DNA profiles ranging in size from 520 to $620 \mathrm{np}$, which had the nature of microsatellite expansions, and were different from the norm profile.

Prospects for further research. In the future, the phenomenon is planned to be studied in practice in order to diagnose neoplastic changes in the epithelium of the gastric mucosa.

\section{References}

1. Bull L. Compound microsatellite repeats: practical and theoretical feautures / L. Bull , C.R Pabon-Pena., N.B. Freimer // Genome Res. - 2000. - №9 . - P. 830 - 838.

2. Chekhun V.F. Funktsional'nyy onkohenom - osnova suchasnoyi diahnostyky ta novoyi stratehiyi protypukhlynnoyi terapiyi / V.F. Chekhun // Onkolohyya. - 2006. - T.8, №2. S.96 - 101[in Ukrainian].

3. Freimer N.B. Microsatellites: evolution and mutational process / N.B. Freimer, M. Slatkin // Ciba Found Symp. - 1996. - №197. - P. 51 - 67.

4. Guttmacher A.E. Welcome to the genomic era / A.E. Guttmacher, F.S. Collins // N Engl J. Med 2003. - №349. - P. 996 - 8.

5. Hernandez M. Interlaboratory transfer of a PCR multiplex method for simeltaneous detection of four genetically modified maize lines: Bt11, MON810, T25, and 
GA21 / M.Hernandez, D.Rodrnguez-Lbzaro, D.Zhang, T.Esteve , M.Pla, S.Plat // Jagric Food Chem. - 2005. Vol.53 - P. 3333 - 3337.

6. Karseladze AI. Nekotoryye osnovopolagayushchiye ponyatiya onkomorfologii v svete dostizheniy sovremennoy molekulyarnoy biologii. Arkh. pat. 2009; (5): 17- 21. [in Russian]

7. Kharchenko OV., Sherstyuk O.O. Naslidky infektsiyi Helicobacter pylori. Svit medytsyny ta biolohiyi. 2018; 3(65): 196 - 199. [in Ukrainian]

8. Kharchenko OV. Mikrosatelitni ekspansiyi - molekulyarno-biolohichnyy fenomen diahnostyky peredpukhlynnykh i pukhlynnykh protsesiv. Svit medytsyny ta biolohiyi. 2015; 2(49): 196 - 200. [in Ukrainian]

9. Markovs'kyy VD, Kharchenko OV. Kompleksna patomorfolohichna dyferentsiyna diahnostyka peredpukhlynnykh protsesiv i raku shlunka. Patolohiya. 2012; (3):15 - 18. [in Ukrainian]

10. Moskvina L.V. Sovremennyye predstavleniya o molekulyarnykh mekhanizmakh progressii raka zheludka / L.V. Moskvina, P.G. Mal'kov // Arkh. pat. - 2010. - Vyp.4. - S. 58 - 62. [in Russian].

11. Vannella L. Risk factors for progression to gastric neoplastic lesions in patients with atrophic gastritis / L.Vannella, E. Lahner, J.Osbom // Aliment. Pharmacol. Ther. - 2010. - Vol.31. - P.1042 - 1050.

12. $\mathrm{Xu}$ X., Peng M., Fang Z. The direction of microsatellite mutations is dependent upon allele length / X.Xu, M.Peng, Z.Fang // Nat Genet. - 2000. - Vol.4. - №4. - P. 396 399. 